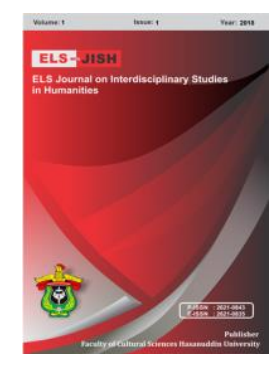

ELS-JISH

ELS Journal on Interdisciplinary Studies on Humanities

Volume 1 Issue 1, 2018

ISSN (print) : 2621-0843

ISSN (online) : 2621-0835

Homepage : http://journal.unhas.ac.id/index.php/jish

\title{
Utilizing Four Square Method (FSM) to Enhance Students' Speaking Ability
}

\author{
Sofyan Sukwara Akfan ${ }^{1}$
}

E-mail: sofyanakfan@gmail.com

\begin{abstract}
This research conducted with the consideration that speaking ability can be enhanced with the implementation of Four Square Method This research was attended to find out the extent to which utilizing Four Square Method in teaching speaking will enhance students' speaking skill or not and to investigate students' perception in utilizing Four Square Method in enhancing their speaking ability. The researcher used a quasi-experimental design involved two groups, they are: an experimental group that used Four Square Method while control group that used traditional method. The data of pre-test and post-test were analyzed by two independent raters by refering to Heaton's speaking band score; while the students perception toward the implementation of Four Square Method was analyzed by using Likert's 'cale. There were 60 participants in this research where 30 in the experimental group and 30 in the control group. They were second grade students of SMAN 1 Baubau. The instruments used were speaking test, questionnaire and recorder. After the data analyzed, the researcher lounched that there is a significant enhancement of students' speaking ability as the mean score of experimental group (accuracy: pre-test 2.80 and post-test 4.07), control group (accuracy: pre-test 3.73 and post-test 3.67). Experimental group (fluency: pres-test 2.70 and post-test 4.10), control group (fluency: pre-test 4.03 and post-test 3.57). Experimental group (comprehensibility: pre-test 2,63 and post-test 3,93) while control group (comprehensibility: pre-test 3.57 and post-test 3.73 ) and experimental group (content: pre-test 2.87 and post-test 4.43) while control group (content: pre-test 4.13 and post-test 4.40). Students' perception toward the implementation of Four Square Method (FSM) was positive; 66.7\% from the students (20) had high interest and 33.3\% (10 students) categorized as moderate. It declares that Four Square Method is effective in enhancing student's speaking ability.
\end{abstract}

Keywords: Four Square Method (FSM), students' speaking ability and students' perception.

How to cite: Akfan, S. S. (2018). Utilizing Four Square Method (FSM) to Enhance Students' Speaking Ability. ELS-Journal on Interdisciplinary Studies in Humanities, 1(1), 44-51.

\section{Introduction}

Language is one of tools used by the human to communicate with another human in daily life. When human uses the language, it reflects his way of thinking. In Indonesia, the students learn English language as a Foreign Language (FL). Furthermore, students are expected to be able to apply many skills in English language such as listening, speaking, reading and writing in their daily activities at school.

The most important ability that students should mastered in learning English as Foreign Language is speaking. It is a complex ability among the other three abilities in English. Moreover, it is believed that speaking as the basic tool to communicate with other

${ }^{1}$ Faculty of Cultural Sciences, Hasanuddin University 
people. Clark \& Clark (1977), demonstrates that speaking is a fundamentally an instrument act. A speaker talks in order to have some effects on his/her listener. Speaking is one of the abilities to produce words in language practice. Speaking is an important ability that students have to master. Sinclair (2003), defines speaking is the use of form nouns which refer to the kind of language used by particular person or by people involved in particular activity. It can be said that there are two people or more than two having a conversation and face to face. Another research was conducted by Itsnaini (2011), her research was about the use of Round Robin technique to improve students' speaking skill. Round Robin is also one of Cooperative Learning techniques. The result of the research showed that Round Robin technique was useful in teaching learning process to improve students' speaking skill. It helped students very much to learn speaking optimally. Kosar \& Bedir (2014), views that learners' speaking ability is an important skill to be improved to make the learners conduct communication directly.

Speaking is used to express thought by using the voice or talk. It means that when someone interacts with other by using a language as a mean, certainly, they want to convey something important. It is strongly impossible for someone to make a communication with other without having any purpose on their speech. Speaking ability requires that learners/students not only know how to produce specific points of language such as grammar, pronunciation, or vocabulary (linguistic competence), but also that they understand when, why, and in what ways to produce language (sociolinguistic competence). Gibson (2004), in his research states about the effectiveness of group working. He revealed that arranging the students in groups of four or five at the beginning of each class is the first step towards developing students' conversation abilities and effectively managing large classes.

As a matter of fact, many students have some problems dealing with speaking. Most of them still feel worry to participate in any conversation and present a topic orally which properly as their speaking ability. From this point onwards, it is became a very challenging for an English teacher to solve those problem.

Teaching speaking is not an easy job. In other words, an English teacher needs to have a good preparation and plan for teaching and learning activities in the class. The preparation includes the teaching method and teaching material. Teachers should be able to monitor the students' abilities to speak. Zhou (2007), states that the $4 / 3 / 2$ technique really enhances Chinese EFL learners' speaking fluency. Therefore, by talking the same topic from 4 minutes to 3 minutes and to 2 minutes, learners' fluency can be gradually enhanced. Moreover, too much nervousness makes learners lost for words and absolutely influences their achievement in foreign language classroom (Zhang \& Jia, 2007).

Additonally, Four Square Method has been applied to the teaching in writing. Rizqi (2012), has carried out the research on the use of Four Square Method to improve students writing skills. The researcher found that using Four Square as a method has proved to be powerful in language learning. Most of the students interested during the lesson by using this kind of method. Students put themselves in a situation they have never experienced before; also it opens the way of thinking and constructs their writing in a paper. Students have improvement their understanding of the writing topic after the researcher were taught them by using this kind of method.

Recently, this method is manipulated by the researcher. The researcher tries to manipuate this method to teach speaking. As Hoang \& Ngoc (2015), mentioned about 
factors that affect the students' speaking performance. In their studies, they just focus to see teachers and students perspective about speaking performance. From both perspectives, the researchers classified as follow: First, majority said that the students' speaking performance was affected by topical knowledge. Secondly, the important factors mentioned were listening ability and motivation to speak. Besides, the teachers' feedback during speaking activities also was also reported to affect the students' speaking performance. Finally, confidence was considered to be a factor that had influence on students' performance.

Thus, based on the explanation above, the appropriate of speaking method that encourage students' speaking activities must be given. Therefore, this research tried to offer the utilizing Four Square Method to be taught to the senior high level students in order that their speaking ability can be enhanced. Thereby, this research aimed to enhance the students' speaking ability by uzing Four Square Method (FSM).

\section{Research Design}

This research used quasi-experimental design with nonequivalent control group design. There were two groups namely experimental and control group which received different treatments. The experimental group was treated by using Four Square Method (FSM), while the control group was treated by traditional method.

\subsection{Population and Sample}

The population of this research was the second grades students of SMAN 1 Baubau. The total number of population was 540 students. The sample of this research was selected by purposive cluster sampling technique. The researcher took two groups that represent as experimental and control group. The sample of this research was 60 students in which 30 students in experimental group and 30 students in control group.

\subsection{Procedures of Collecting Data}

The researcher used two kinds of instruments to collect the data; those are speaking test and questionnaire. The speaking test was used to assess the students' learning achievement before and after receiving some treatments. After doing the posttest, the researcher distributed questionnaire in the last activity for experimental group. The questionnaire aimed to find out the students' perceptions during the process of teaching speaking by uzing Four Square Method (FSM).

In collecting the data, both groups were given pretest firstly. The aim of giving pretest was to find out the students' prior knowledge. The result of pretest was compared to the result of posttest which was given in the final session. Then the treatment was given in eight meetings which delivered 90 minutes for each meeting. After giving the treatment, both groups were given posttest to find out the students' achievement in speaking ability after having several teaching processes.

\subsection{Technique of Analyzing Data}

The students' speaking recording was transcribed. The transcription was analyzed using the following speaking's criteria level. Four points to be noticed for this speaking's criteria are; accuracy, fluency, comprehensibility and content. 


\section{Reseach Findings}

Based on the result of the research, first in the pre-test of accuracy, the mean score for experimental group was 2.80 and after treatment the mean score was 4.07. From the score, it can be concluded tha the students' mean score showed progress after the treatment. Then for the control group, the changing of the mean score when the pre-test conducted was 3.73 and the standard deviation was 0.817 . However, after treatment the mean score of the control group was 3.67 and the standard deviation was 0.606 . From the mean score of both groups, the researcher concluded that there was improvement. When the pre-test was conducted there were 36.38 percent (22 students) high achievers while 63.35 percent (38 students) were called low achievers. Then the treatment was conducted, the post-test was done and the result showed the difference in both groups where there were 31.65 (19 students) categorized as the low achievers while there were 58.35 (41 students) categorized as the high achievers.

Secondly, the mean score of fluency for the experimental group when pre-test conducted was 2.70 with standard deviation 0.651. After treatment was conducted, the mean score became 4.10 with standard deviation 0.504 . It clearly that there was progress significantly but just in the experimental group. When the pre-test was conducted there were 35 percent ( 21 students) high achievers while 65 percent (39 students) were called low achievers. Then the treatment was conducted, the post-test was done and the result showed the difference in both groups where there were 32.15 (19 students) categorized as the low achievers while there were 68.35 (41 students) categorized as the high achievers.

Next, the pre-test mean score of comprehensibility for the experimental group was 2.63 and after treatment the mean score for the post-test was 3.93. It indicates there was enhancement after the treatment where the experimental group was much higher than control group. While, in the control group when the pre-test was conducted the mean score was 3.57 and after post-test become 3.73. when the pre-test carried out for the experimental group and control group there were 22,65 percent (19 students) as high achievers and there were 68,3 percent (41 students) as low achievers. Anyhow, when the post-test was conducted there were 54.8 percent (41 students) as high achievers and there were 31,7 percent (19 students) as low achievers. It can be concluded that there were many more high achievers than low achievers on comprehensibility.

Lastly, the pre-test mean score of content for the experimental group was 2.87 and after treatment the mean score for the post-test was 4.43. It indicates there was enhancement after the treatment where the experimental group was much higher than control group. While, in the control group when the pre-test was conducted the mean score was 4.13 and after post-test become 4.40. that when the pre-test was conducted there were 46.65 percent (28 students) categorized as high achievers and 53.35 percent (32 students) as low achievers, while when the post-test was conducted there was a change. For the post-test the high achievers were 94.95 (57 students) and there were 5 percent (3 students) as low achivers. 
3.1. The Students' Improvement of Experimental Group and Control Group in Terms of Accuracy

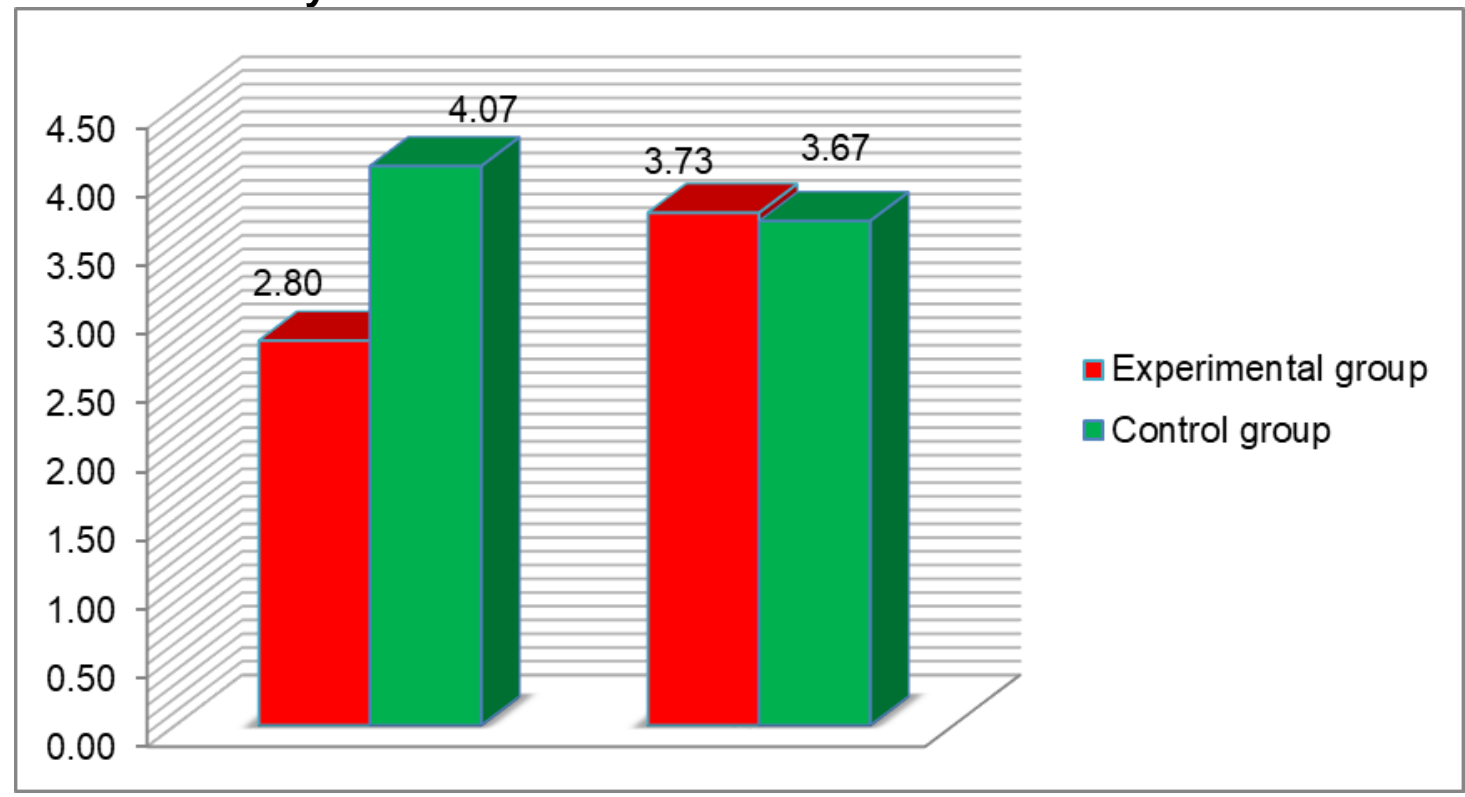

Picture 1 illustrates in the pre-test, the mean score for experimental group was 2.80 and after treatment the mean score was 4.07. From the score, it can be concluded tha the students' mean score showed progress after the treatment. Then for the control group, the changing of the mean score when the pre-test conducted was 3.73 and the standard deviation was 0.817 . However, after treatment the mean score of the control group was 3.67 and the standard deviation was 0.606 . From the mean score of both groups, the researcher concluded that there was improvement.

3.2. The Students' Improvement of Experimental Group and Control Group in Terms of Accuracy

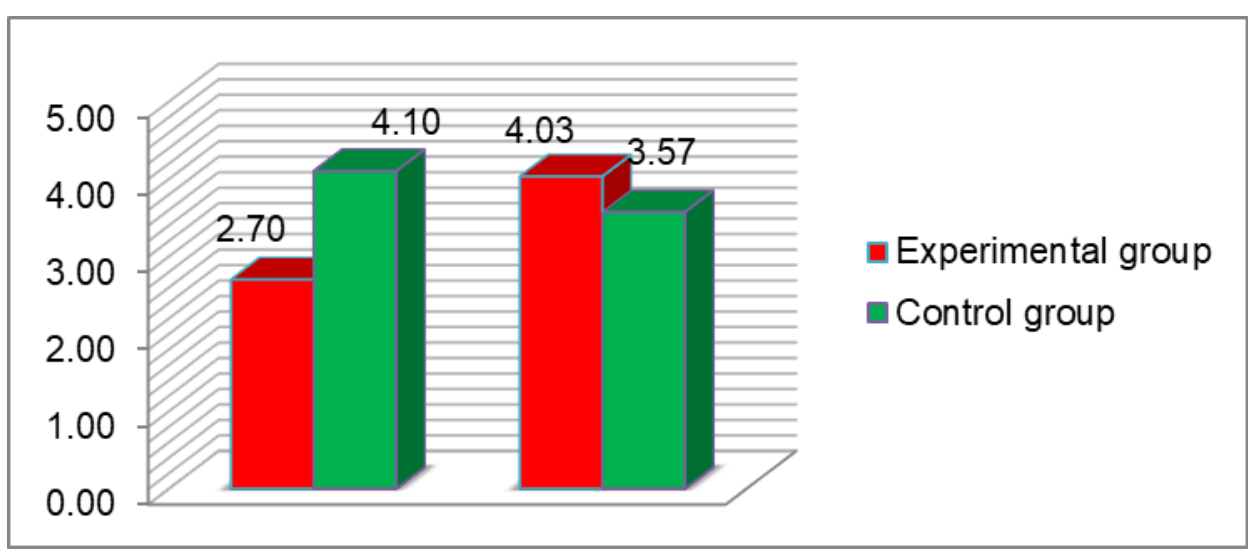

Picture 2 illustrates that the mean score for the experimental group when pre-test conducted was 2.70. After treatment was conducted, the mean score became 4.03. While the mean score pre-test in control group was 4.10 and after post-test became 3.57. It clearly that there was progress significantly but just in the experimental group.

\subsection{Students' Improvements of Experimental and Control Group in terms of Comprehensibility.}




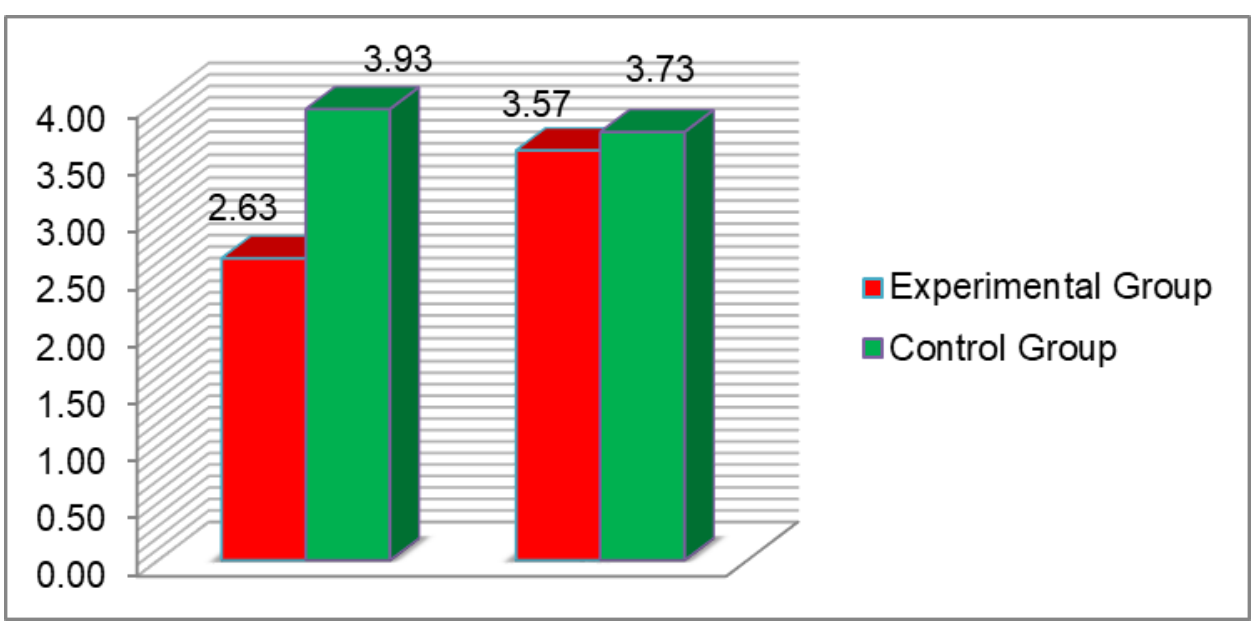

Picture 3 shows that the pre-test mean score for the experimental group was 2.63 and after treatment the mean score for the post-test was 3.93. It indicates there was enhancement after the treatment where the experimental group was much higher than control group. While, in the control group when the pre-test was conducted the mean score was 3.57 and after post-test become 3.73.

\subsection{Students' Improvements of Experimental and Control Group in terms of Content.}

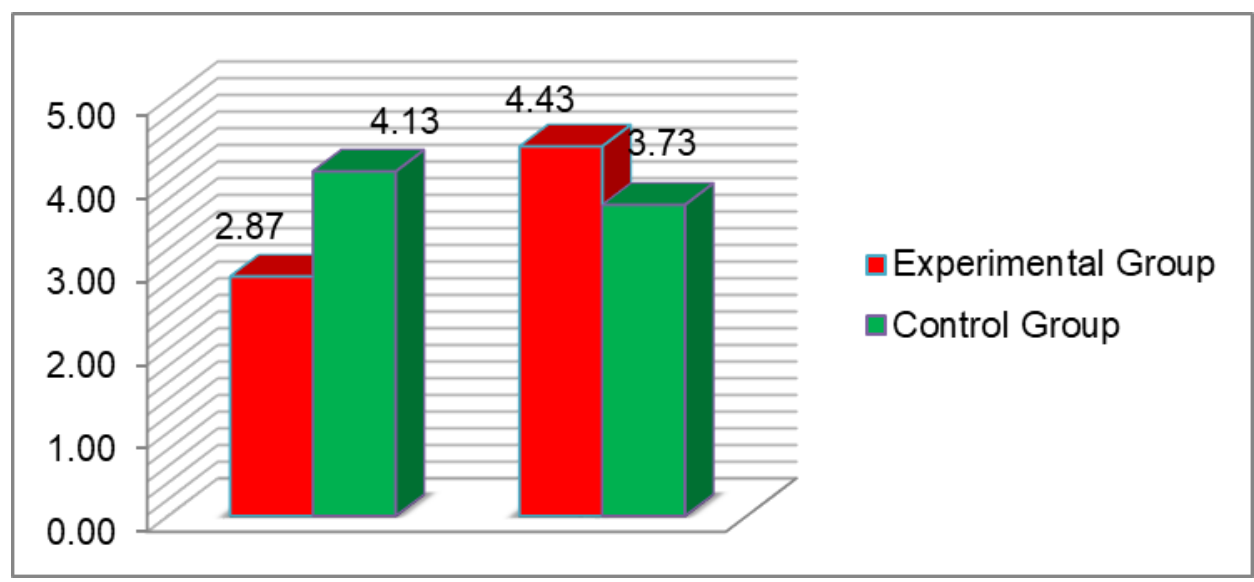

The chart above shows that the pre-test mean score for the experimental group was 2.87 and after treatment the mean score for the post-test was 4.43. It indicates there was enhancement after the treatment where the experimental group was much higher than control group. While, in the control group when the pre-test was conducted the mean score was 4.13 and after post-test become 4.40 .

It can be concluded that after treatment experimental group's mean score higher than control group. The use of Four Square Method (FSM) increased the students' speaking ability. As there were 66.7 percent (20 students) categorized had high interest on the application of experiential learning in teaching speaking and 33.3 percent (10 students) categorized moderate. Mostly, students in experimental group had high interest or positive respond toward the application of Four Square Method (FSM).

\section{Discussion}

This research showed the use of personal experience may dig students' ability to enhance their skill in English since Four Square Method is apllied to see how the method provided students to have a good crtical thinking of understanding every matter that dealt 
with them. The application of Four Square Method made students had many opportunities to dig their experiences to be told for all class and the ideas that the students already had in their mind sometimes difficult to be explained and in fact because they did not know what is appropriate word to use correctly in a sentence. The use of Four Square Method required the teachers to be more creative and innovative to predict which material can be used to dig students' experiences, according to $\mathrm{Ng}$ \& Lan (2004), declares that a professional teacher is one who regularly reflects on his or her teaching through critical thinking. The use of Four Square Method could uncover the obstacles and discover how teachers' teaching belief needs to change in order to implement the new method of teaching. Especially to figure out students' difficulties in speaking, in this research there were some students' difficulties, for instance; students could not differentiate singular and plural nouns, the omission of $-\mathrm{s}$ suffix in predicate as the third person singular, the use of verb form before modal and inappropriate word order, repeating words, artificial pauses, and deliberate halting. General feedback is need but it can be done at the end of class without interrupted students' utterances. As it supported by Snow (1996), stated that 'Some correction of students' errors may be helpful, but there is a little evidence that correction is of much benefit in improving students' accuracy. Over correction can make students self-conscious and discourage them from speaking".

Further, in this research, the use of topic that related to their personal experience as the material dig students' wilingness to speak. It can be seen from there were a great number of students who have a big interest on the use of Four Square Method. The reseacher thought that Four Square Method can be used in classroom for any level and using different materials for instance: picture, Indonesian story or article of hot issue recently happening but must be considering with their ability.

Taking the hot issue happening such a global issue not only contribute a new knowledge of the students since Four Square Method encourages them to talk, but also can combine the use of source material taken from issues happening around the students' environment then insight of knowing new thing can gain as well the language learning.

Four Square Method causes the students to get many opportunities to do reflection to themselves, since in Four Square Method teacher gives feedback on each other's experience: it allowed the students to demonstrate their speaking ability. Furthemore, through Four Square Method students can share their voice, doubts, struggles, discomfort, happy and unhappy, which might be reinforced students confidence and motivation in language learning.

\section{Conclusion}

The use of Four Square Method in teaching speaking improved the students' speaking ability, as Four Square Method (FSM) was taught in experimental group and the students' mean score of the students' post-test is higher than control group. As shown in ttest, in terms of accuracy experimental group for post-test mean score was 4.07, while control group's mean score for accuracy was 3.67. Fluency for experimental group after treatment mean score was 4.10 , while control group group 3.57. Comprehensibility after treatment experimental group's mean score was 3.93 while in control group 3.73. Content for experimental group's mean score when post-test conducted was 4.43, while in control group the score was 4.40. It can be concluded that after treatment experimental group's mean score higher than control group. Because of this, the use of Four Square Method (FSM) enhanced students' speaking ability in experimental group while the use of 
traditional method enhanced the students' speaking ability but not really significant. The researcher may conclude that Four Square Method (FSM) can enhanced students' ability not only for writing but also for speaking. Mostly students in experimental group had high interest or positive respond toward the application of Four Square Method (FSM). The researcher suggest to the future researchers to conduct similiar technique that is Four Square Method but use and combine different skills for examples: Reading, Writing and even Listening.

\section{References}

Clark H. H. \& Clark E. V. (1977). Psychology and Language. Horcourt Brace Javanoich. New York. Stanford University.

Gibson G. (2004). Facilitating English Conversation Development in Large Classrooms. The Internet TESL Journal, 10(9).

Hoang N. T \& Ngoc T. M. (2015). Factors Affecting Students' Speaking Performance At Le Thanh Hien High School. Asian Journal of Educational Research, 3(2): 8-23.

Itsnaini H. (2011). The Use of Round Robin Structure to Improve Students' Speaking Skills. Final Project English Department FBS Unnes. Thesis. Accesed on 30 May 2017. Avalaible from http://lib.unnes.ac.id/7642/.

Kosar G. \& Bedir H. (2014). Strategies-Based Instruction: A Means of Improving Adult EFL Learners' Speaking Skills. International Journal of Language Academy, 2(3).

$\mathrm{Ng}$ \& Lan. (2004). Developing Reflective Teachers: The Experience of Two Modules in the Teacher Training Programme at the National Institute of Education, Singapore. Asia Pacific Education Review. 5 (2): 200-206.

Rizqi K. N. (2012). Improving Students' Writing Skill Using Four Square Writing Method at SMA Negeri 1 Ngemplak Boyolali. Published Version. Universitas Sebelas Maret. Thesis. Accesed on 15 January 2017. Avalaible from https://eprints.uns.ac.id/id/eprint/11302.html.

Sinclair J. (2003). Collins Cobuild Advanced Learners English Dictionary, $4^{\text {th }}$ edition. Glasgow: Harper Collins Publishers, p. 1452.

Snow D. (1996). More Than a Native Speaker. An Introduction for Volunteers Teaching Abroad. Pantagraph Printing. Illinois Usa.

Zhou, A. J. (2007). A Further Study of the Effects of the 4/3/2 Technique on Spoken English Production. CELEA Journal, 29(1): 12-20.

Zhang, Y. L., \& Jia, G. Z. (2007). Anxiety in Foreign Language Classroom. CELEA Journal, 29(6): 96-103. 